\title{
CKS1B Gene
}

National Cancer Institute

\section{Source}

National Cancer Institute. CKS1B Gene. NCI Thesaurus. Code C104980.

This gene plays a role in the regulation of cyclin dependent kinase activity. 